\title{
LYMPHOMATOUS MENINGOENCEPHALITIS IN A PATIENT WITH HAM/TSP
}

\author{
IRENIO GOMES*, MARCO HELENO CUNHA NASCIMENTO* *, \\ OTAVIO AUGUSTO MORENO-CARVALHO***, AILTON MELO****
}

SUMMARY - A case of lymphomatous meningoencephalitis in a 23 year old Brazilian patient with HTLV-I/II associated myelopathy is reported. The patient was admitted to the hospital with a clinical picture of decreased consciousness level, stiffness of the neck and previous diagnosis of myeloneuropathy. CSF examination showed lymphocytosis with blastic cells and antibodies against HTLV-I/II.

KEY WORDS: HTLV-I, meningoencephalitis, lymphoma.

\section{Meningo-encefalite linformatosa em um paciente com HAM/TSP}

RESUMO - É descrito o caso de um paciente de 23 anos, com diagnóstico prévio de mielorradiculopatia que desenvolveu diminuiçăo gradual do nível de consciência, rigidez de nuca e cefaléia. O exame do LCR mostrou linfocitose com presença de células blásticas, hiperproteinorraquia e anticorpos para HTLV-I/II.

PALAVRAS-CHAVE: HTLV-I, meningo-encefalite, linfoma.

Endemic in several areas of the world, the nervous system involvement by the human T-cell lymphotropic virus type I (HTLV-I) has been described as myelopathy or myeloneuropathy (HAM/ TSP) by several authors ${ }^{1,4,12}$. Although the most prominent neuropathological changes in HAM/TSP are a chronic inflammatory process of the thoracic spinal cord, eletrophysiological, radiological and histopathological studies ${ }^{5-7,13}$ have demonstrated brain and peripheral involvement of the nervous system characterizing a neurologic picture of encephalomyeloneuropathy.

In this paper we will describe a patient with HAM/TSP who developed a sudden decreased level of consciousness associated with stiffness of the neck. CSF examinations showed lymphocytosis with lymphomatous cells.

\section{CASE REPORT}

RPS, a 23 years old man from Salvador-Bahia was admitted to the hospital because of a sudden picture of headache and somnolence. The patient was well until two or three months earlier, when he began to experience progressive paraparesis and burning sensations in lower limbs. Two weeks before being admitted he developed headache, back pain and somnolence. Neurologic examination showed intact mentation, fluent speech and moderate stiffness of the neck. The left eye had hypopion and midriasis with slightly reaction to light; the right

*Neurologista da Unidade de Neuroinfectologia da Universidade Federal da Bahia (UFBA); **Monitor do Departamento de Neuropsiquiatria, UFBA; ${ }^{* * *}$ Responsável pelo Laboratório de Liquorologia do Hospital Santo Amaro, Salvador; ****Responsável pela Unidade de Neuroinfectologia da UFBA, Pesquisador do CNPq. Aceite: 28-setembro-1994. 


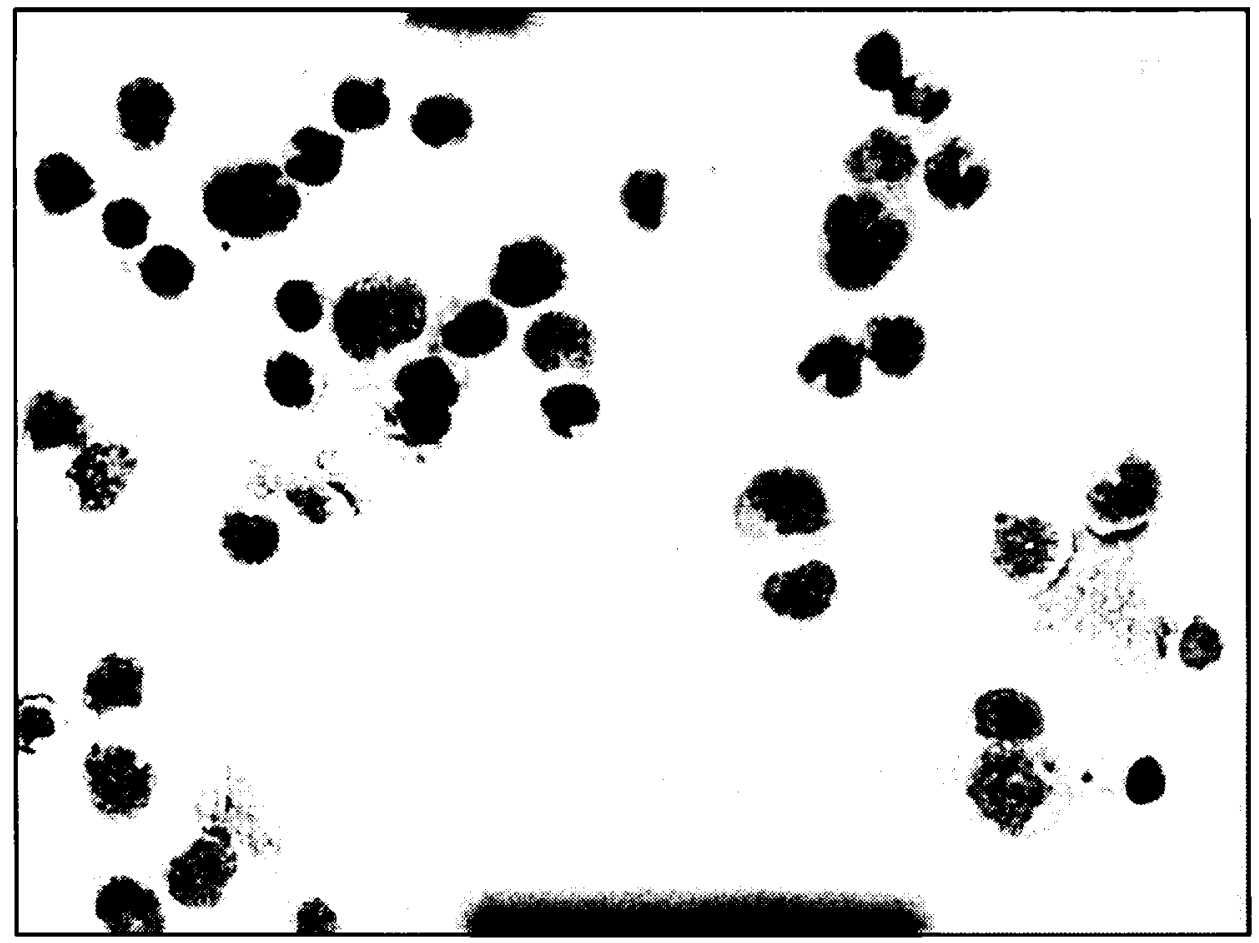

Fig 1. Light microscopic appearence of neoplastic linforeticular cells in the CSF of the patient with chronic meningoencephalitis associated to HAM. Atypical lymphocytes with nuclear identation are seen (original magnification $x 400$ ).

eye had no abnormality. Optic fundi and the remaining cranial nerves were normal. Intrinsic muscles of feet and distal portion of legs were atrophic. Tone was decreased in both legs as well as strenght in lower limbs (grade $2 J$ 5). Patellar and Achilles reflexes were absent, the plantar responses were flexor. Cutaneous abdominal reflexes were absent and a T7 superficial sensitive level was found. There was a decrease in vibratory and proprioceptive sensation in the distal portions of the lower extremities. The hematocrit was $43 \%$; hemoglobin $14 \mathrm{~g} \%$; whitecell count was 20,500 with $66 \%$ neutrophils, $27 \%$ lymphocytes, $6 \%$ monocytes and $1 \%$ eosinophils; blastic cells were not found in the peripheral blood; glucose was $91 \mathrm{mg} \%$, sodium $146 \mathrm{mEq} / \mathrm{l}$, potassium $3.3 \mathrm{mEq} /$, creatinine, $1.1 \mathrm{mg} \%$ and urea $30 \mathrm{mg} \%$. Screening test to HIV was negative. CSF examination showed: 445 cells $/ \mathrm{mm}^{3}$ with lymphocytes $70 \%$ monocytes $27 \%$, neutrophilis $1 \%$, and presence of blastic cells suggestive of lymphoma (Fig 1); glucose $5 \mathrm{mg} \%$; proteins $830 \mathrm{mg} \%$; antibodies to syphillis, toxoplasmosis, cysticercosis or schistosomiasis were not detected. Antibodies to HTLV-I were presented in sera and CSF. ELISA to HIV in sera was negative. CT scan of the brain did not show any abnormality. His condition was gradually worsening over the ensuing two weeks and he died of a massive pulmonary embolus and cardiac arrest. Permission for autopsy was refused.

\section{COMMENTS}

A high incidence of HTLV-I carriers has been proven to occur in some areas of Brazil.1.11. In Salvador the number of infected persons is specially high which means a higher prevalence of HAM cases and also higher probability of atypical presentations".

The initial idea that HTLV-I was related to myelopathy or adult T-cell leukemia was changed to the current concept that it is an immunological and systemic disease whose clinical manifestations are mainly in the nervous and hematological systems, with pleomorphic involvement in different 
organs and systems ${ }^{4.5}$. Several reports have referred systemic manifestations associated with nervous system involvement ${ }^{4,810}$. In this case a lymphomatous meningoencephalitis has developed in a patient with a clinical picture of HAM/TSP. These data lead us to think that an immune response may be triggered by the virus to develop different clinical manifestations. These factors could be genetic (HLA haplotypes), infectious (co-infection with $S$. stercoralis or other parasitic agents) or environmental. Sporadic cases of adult T-cell leukemia-lymphoma (ATLL) alone ${ }^{2}$ or associated to HAM $^{9}$ have been found in Salvador. Meanwhile, Clinical or laboratory findings of ATLL in this patient did not support the diagnosis of HAM/ATLL.

It would be interesting to verify, in an endemic area of HTLV-I and other infectious diseases as Salvador, which co-factors would be related to different manifestations of HTLV-I disease.

Acknowledgements - We are indebted to Professor Aristides Chetto de Queiroz for his kind assistance.

\section{REFERENCES}

1. Arango C, Concha M, Zaninovic V, Corral R, Biojo J, Borrero I, Rodgers-Johnson P, Mora C, Garruto RM, Gibbs CJ Jr. Epidemiology of tropical spastic paraparesis in Colombia and associated HTLV-I infection. Ann Neurol 1988, 23(Suppl): S161-S165.

2. Bittencourt AL, Fernnandes DJ, Sampaio C, Moreira ED Jr, Ribeiro TT, Harrington W Jr. HTLV-I associated cutaneous T-cell lyphoma: report of a case with atypical clinical presentation. Mem Inst Osw Cruz (in press).

3. Cortes E, Detels R, Aboulafia D, Li XL, Maudgil T, Alan M, Bonecker C, Gonzaga A, Oyafuso L, Tondo M. HIV-1, HIV-2 and HTLV-1 infection in high risk groups in Brazil. N Engl J Med 1989, 220:953-958.

4. Gessain A, Gout O. Chronic myelopathy associated with human T-lymphotropic virus type I (HTLV-I). Ann Intern Med 1992, 117:933-946.

5. Iwasaki Y. Human T cell leukemia virus type-I infection and chronic myelopathy. Brain Pathol 1993, 3:1-10.

6. Melo A, Moura L, Rios S, Machado M, Costa G. Magnetic resonance imaging in HTLV-I associated myelopathy. Arq Neuropsiquiatr 1993, 51:329-332.

7. Melo A, Gomes I, Mattos K. Mielopatia por HTLV-I: uma doença sistêmica. Arq Neuropsiquiatr 1994, 52:443-444.

8. Melo A, Gomes I, Mattos K. Mielopatia por HTLV-I/II em Salvador/Bahia. Arq Neuropsiquiatr 1994, 52:320-325.

9. Melo A, Freitas V, Bittencourt AL, Fernandes DJ, Mattos K, Gomes I. Adult T-cell leukemia-lymphoma in a patient with HTLV-I/II associated myelopathy. J Neurol 1994, 241: S6.

10. Mattos K, Queiroz C, Peçanha-Martins AC, Publio L, Vinhas V, Melo A. Lymphocyte alveolitis in HAM TSP patients. Arq Neuropsiquiatr 1993, 51:134-136.

11. Moreira ED Jr, Ribeiro TT, Swanson P, Sampaio C, Melo A, Brites C, Badaro R, Toedter G, Lee H, Harrington W Jr. Seroepidemiology of human T-cell lymphotropic virus type I/II in Northeastern Brazil. J AIDS 1993, 959-963.

12. Osame M. Igata A, Matsumoto M, Kohka M, Usuku K, Izumo S. HTLV-I associated myelopathy: treatment trials, retrospective survey and clinical and laboratory findings. Hematol Rev 1990, 3: 271-274.

13. Said G, Goulon-Goeau C, Lacroix C, Feve A, Descamps H, Fouchard M. Inflammatory lesions of peripheral nerve in a patient with human T lymphotropic virus type I-associated myelopathy. Ann Neurol 1988, 24:275-277. 